\title{
Antibiotics in Crop Production ${ }^{1}$
}

\author{
Leigh Archer, Ute Albrecht, and Pamela Roberts ${ }^{2}$
}

\section{Introduction}

Plant diseases caused by bacteria are widespread and devastating. Bacterial diseases can be particularly difficult to control because bacteria reproduce rapidly, can be spread by wind, rain, insects, other animals, or even human beings, and often reside within plant tissues such as leaves or the vascular system. Management of diseases caused by bacteria is most effective through an integrated approach. This includes host resistance, when it is available, and applications of bactericides, biological control agents, or systemic acquired resistance (SAR) inducers. It also includes sanitation (i.e., removing diseased tissue, removing infected plants, cleaning tools) and cultural practices (i.e., increasing air flow, avoiding overhead irrigation, avoiding field operation when plants are wet). Among the bactericides, antibiotics are often used to treat plants for managing bacterial diseases. Although originally antibiotics were compounds produced by microorganisms to inhibit other microorganisms, many synthetic antibiotics are now available. Antibiotics can be bactericidal, which means they kill bacteria, or they can be bacteriostatic, which means they inhibit growth of bacteria but do not kill them. Two antibiotic compounds that have been widely used in agriculture in both plant and animal systems are streptomycin and oxytetracycline. Streptomycin, originally produced by the actinomycete Streptomyces griseus, disrupts bacterial protein synthesis. Although the exact mechanisms of action are not fully understood, streptomycin is considered bactericidal. Oxytetracycline also interferes with the ability of bacteria to produce proteins but is considered bacteriostatic. Like streptomycin, oxytetracycline and the more recently used kasugamycin were originally produced by soilborne microorganisms in the Streptomyces group. The use of these antibiotics has resulted in the successful control of bacterial diseases in some crops but not in others. This article provides an overview of antibiotic use in agriculture and in plant disease management.

\section{Antibiotic Uses in US Agriculture}

Although antibiotics are permitted in certain plant systems, their use in agriculture is concentrated towards animal production (Stockwell and Duffy 2012). In 2017, antibacterial drugs sold and distributed for animal use in the United States were estimated by the Food and Drug Administration (FDA) to be 10.9 million kilograms of active ingredient applied (Table 1). This is reduced by $30 \%$ from the 2015 peak of an estimated 15.6 million kilograms for livestock.

Estimates by the EPA and USDA for antibiotic use in plant agriculture during 2017 suggest that 38,500 kilograms of streptomycin and 47,200 kilograms of oxytetracycline were used in apple, peach, orange, and pear orchard systems, with minimal usage in all other crops (Table 2: USDANASS 2017). This amount represents less than $0.8 \%$ of the total used in animal agriculture over the same period. A recent emergency exemption by the EPA allows Florida growers to apply up to 176,700 kilograms of oxytetracycline to combat HLB (huanglongbing) in citrus while other integrated control strategies and resistant citrus cultivars are developed. While this number still represents only $1.1 \%$

1. This document is HS1366, one of a series of the Horticultural Sciences Department, UF/IFAS Extension. Original publication date May 2020. Visit the EDIS website at https://edis.ifas.ufl.edu for the currently supported version of this publication.

2. Leigh Archer, graduate assistant, Horticultural Sciences Department; Ute Albrecht, assistant professor, Horticultural Sciences Department; Pamela Roberts, professor, Plant Pathology Department; UF/IFAS Southwest Florida Research and Education Center, Immokalee, FL 34142.

The Institute of Food and Agricultural Sciences (IFAS) is an Equal Opportunity Institution authorized to provide research, educational information and other services

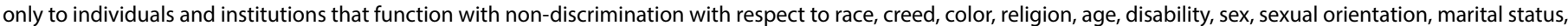

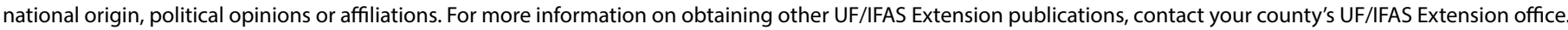
U.S. Department of Agriculture, UF/IFAS Extension Service, University of Florida, IFAS, Florida A \& M University Cooperative Extension Program, and Boards of County Commissioners Cooperating. Nick T. Place, dean for UF/IFAS Extension. 
of the amount used for animal production, researchers are investigating options for targeted application to reduce any potential negative side effects on human health and the environment resulting from widespread foliar applications.

Table 1. Domestic sales of antibiotics for use in livestock expressed in kilograms of active ingredient (a.i.).

\begin{tabular}{|l|c|c|c|}
\hline \multicolumn{4}{|c|}{2017 Domestic Sales of Antibiotics for Livestock } \\
\hline & $\begin{array}{c}\text { Not Medically } \\
\text { Important }\end{array}$ & $\begin{array}{c}\text { Medically } \\
\text { Important }\end{array}$ & \\
\hline Commodity & kg (a.i.) & kg (a.i.) & Total (kg) \\
\hline CATTLE & $3,139,331$ & $2,333,839$ & $5,473,170$ \\
\hline SWINE & 395,994 & $2,022,932$ & $2,418,926$ \\
\hline CHICKEN & $1,477,197$ & 268,047 & $1,745,244$ \\
\hline TURKEY & 358,774 & 670,831 & $1,029,605$ \\
\hline OTHER & 2,860 & 263,564 & 266,424 \\
\hline
\end{tabular}

${ }^{1}$ Any antimicrobial drug class not listed in Appendix A of FDA's Guidance for Industry \#152.

${ }^{2}$ All antimicrobial drugs listed in Appendix A of FDA's Guidance for Industry \#152 considered "medically important" in human medical therapy.

Source: FDA 2017 summary report on antimicrobials sold or distributed for use in food-producing animals.

Table 2. Domestic sales of antibiotics for use in tree crops expressed in kilograms of active ingredient.

\begin{tabular}{|l|c|c|c|}
\hline \multicolumn{4}{|c|}{2017 Domestic Application of Antibiotics in Tree Crops } \\
\hline Commotracycline & Streptomycin & \\
\hline APPLES & 10,773 & kg (a.i.) & Total (kg) \\
\hline GRAPEFRUIT & 2,136 & -- & 31,182 \\
\hline ORANGES & 30,545 & 14,909 & 2,136 \\
\hline PEACHES & 2,500 & -- & 45,455 \\
\hline PEARS & 909 & 3,273 & 2,500 \\
\hline TANGERINES & 364 & -- & 4,182 \\
\hline Source: USDA-NASS 2017. & & 364 \\
\hline
\end{tabular}

\section{Fire Blight of Pome Fruit}

Fire blight is a devastating bacterial disease of apples, pears, and other pome fruits, caused by Erwinia amylovora. The bacteria infect blossoms and can spread through the vascular system and infect other parts of the tree, including shoot tips, fruits, stems, and the rootstock (Figure 1).

Because of the systemic spread of the bacterium, whole-tree losses due to fire blight are common. In addition to the spread of bacteria within trees, they can be spread from infected tissue to new sites by insects and rain. Integrated management practices, including reduction of inoculum through sanitation and exclusion and use of chemical or biocontrol agents, can help keep the disease under control. Resistant apple and pear cultivars have been developed and offer growers the most effective management options.
Copper compounds can be effective in reducing the inoculum but can only be used during the prebloom phase. The most effective method for the blossom phase of the disease is the use of antibiotics.

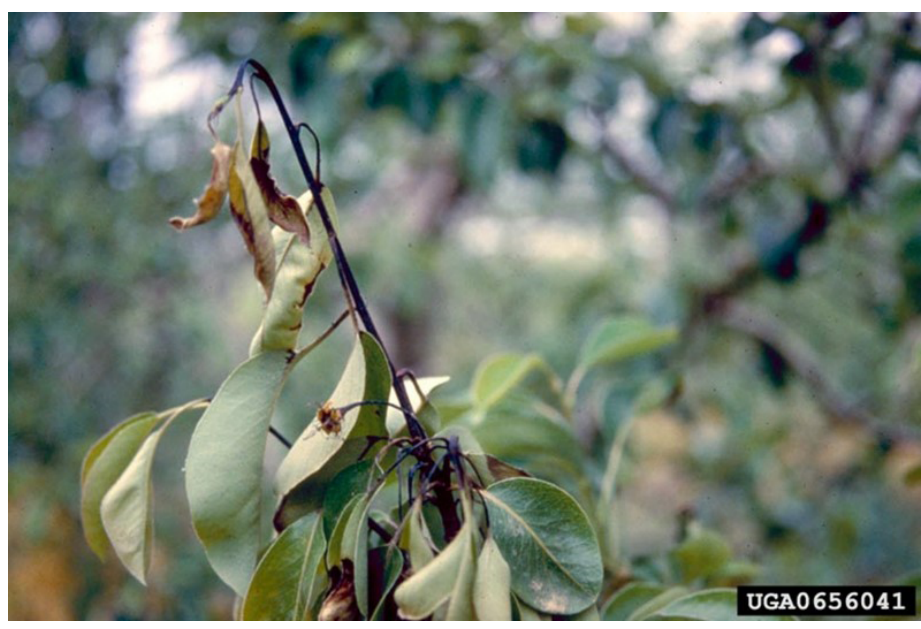

Figure 1. Fire blight symptoms on pear shoot tip.

Credits: P. G. Psallidas, Benaki Institute, Athens, Bugwood.org

In apples and pears, the availability of bactericides to control fire blight was a significant turning point in the management of the disease. Spray applications of streptomycin became the most widely used method to protect the flowers. However, the continued use of streptomycin led to significant selection of resistant E. amylovora in orchards across the country (Loper et al. 1991). In the 1980s, growers began using oxytetracycline to combat the development of resistance. However, oxytetracycline is generally less effective compared to streptomycin because it does not kill existing bacteria. When used as foliar sprays, both are most effective at preventing the growth of bacterial populations when they are applied prior to a rain event. However, oxytetracycline is very sensitive to degradation by sunlight and can be easily washed off the leaf surfaces during rain events. Growers generally have had more success with the application of streptomycin and, more recently, kasugamycin.

\section{Bacterial Spot of Stone Fruit}

Bacterial spot of peaches and related Prunus fruit species is another disease where spray applications of antibiotics have been used to provide some degree of control in an integrated management program. This disease is caused by the bacterium Xanthomonas arboricola pv. pruni and is particularly problematic for peaches and nectarines growing in regions with warm, wet summers. Apricots, plums, and cherries are also susceptible. Symptoms of the disease include spots on leaves and fruit, twig cankers, and in severe cases, tree defoliation (Figure 2). Severe disease is often found in fields with light, sandy soil where windblown sand can cause open wounds and lesions on leaves, which 
bacteria can readily infect. Highest susceptibility exists after shuck split and again for several weeks before harvest. Control of bacterial spot is difficult, and the use of resistant cultivars and other cultural practices, such as isolation of susceptible cultivars, are recommended. Chemical control may be achieved by foliar sprays of oxytetracycline in combination with copper-based materials. However, sprays must be applied preventively when fruits are most susceptible.

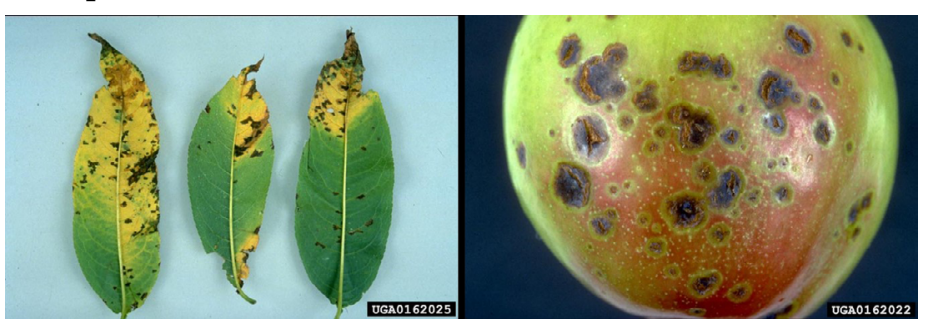

Figure 2. Bacterial spot symptoms on peach leaves (left) and plum fruit (right).

Credits: U. Mazzucchi, Università di Bologna, Bugwood.org

\section{Citrus Canker}

Citrus canker is caused by the bacterium Xanthomonas citri subsp. citri. The disease is endemic in Florida citrus following the latest of many introductions in 1995. The disease is particularly severe on grapefruit and was a major contributor to the decline of grapefruit production in Florida. This decline was a result of the area-wide eradication program and the extensive spread of the disease during the hurricanes in 2004-2005. Symptoms of the disease are lesions on leaves, twigs, and fruit causing premature fruit drop and unmarketable fruit (Figure 3). As with other bacterial pathogens, the inoculum spreads via wind-driven rain, which is of particular concern in Florida because of the frequent rains during the summer season. No citrus cultivars are immune to citrus canker; however, some cultivars, such as tangerines, Valencia oranges, and other mandarin-type cultivars, are less susceptible. Many growers rely primarily on the use of copper-based sprays, although copper accumulation in the soil and potential phytotoxicity limit the excessive or continuous use of these materials. Spray applications of streptomycin in combination with copper sulfate were shown to provide partial disease control (Graham et al. 2010). In 2014, an emergency exemption (section 18) was approved by EPA, allowing the use of a hydrochloride formulation of streptomycin on Florida grapefruit. The combination of streptomycin and copper can increase efficacy and may reduce some of the risk in selecting for antibiotic resistant bacteria. For more information on citrus canker, see https://edis.ifas.ufl.edu/pp116.

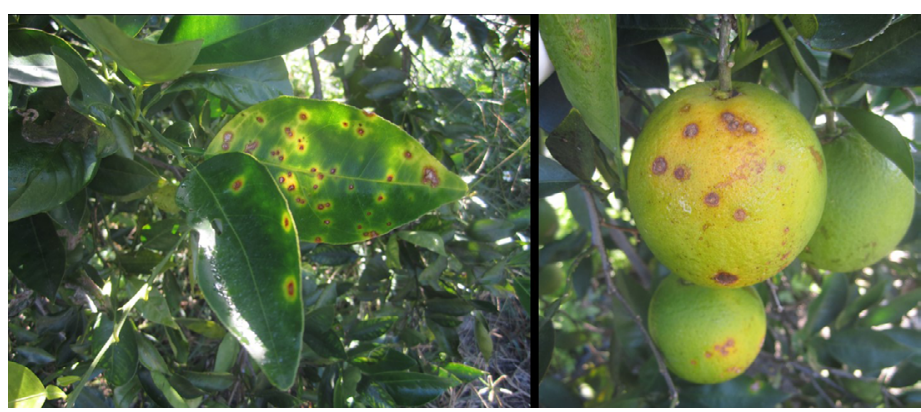

Figure 3. Citrus canker lesions on leaves (left) and fruit (right). Credits: Pamela Roberts, UF/IFAS

\section{Huanglongbing (Citrus Greening)}

Huanglongbing (HLB), a.k.a. citrus greening, is a bacterial disease that is endemic in Florida and other citrus-producing regions around the world, with devastating effects to the industry. The disease is associated with the phloem-limited bacterium Candidatus Liberibacter asiaticus (CLas), which is vectored by the Asian citrus psyllid. Although HLB likely emerged in Asia in the late 1800s, it was not identified in Florida until 2005. Symptoms of the disease include blotchy yellow mottling of the leaves and chlorosis, which are often mistaken for nutritional deficiencies (Figure 4). Fruit on affected trees are small, poorly colored, and misshapen, are of bitter flavor, and drop prematurely. No resistant cultivars are available, although some cultivars can tolerate the disease better than others can. To prevent infection, vector control is essential; once trees are infected, control of the disease is very difficult.

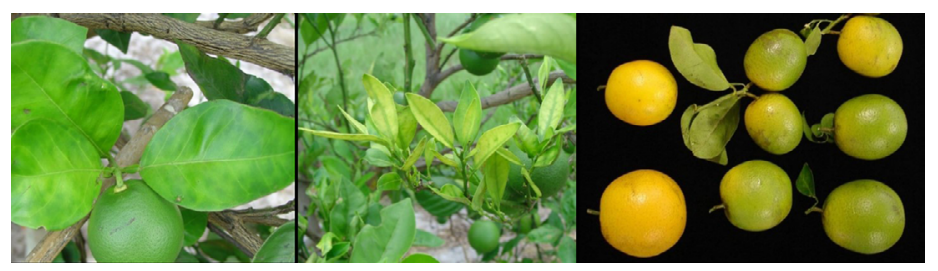

Figure 4. HLB symptoms on leaves and fruit. Credits: Ute Albrecht, UF/IFAS

In 2015, a special-use emergency exemption (section 18) was approved by the EPA, which allowed the foliar use of streptomycin sulfate, oxytetracycline hydrochloride, and oxytetracycline calcium in Florida to suppress CLas and improve tree health. Use of antibiotics for HLB control was investigated in other countries during the 1970s and 1980s and showed some efficacy, particularly when the materials were injected into the tree (Da Graça 1991). Widespread foliar sprays of antibiotics in commercial citrus orchards in Florida have not yielded the desired results. Recent research showed reduction of pathogen levels and suppression of disease symptoms when oxytetracycline was applied by trunk injection (Hu and Wang 2016). However, this method is currently not labelled for commercial use. Until resistant cultivars are available, growers will have to continue to 
use an integrated management program including vector control, nutrition and irrigation management, and other strategies to control the disease and manage tree health.

For more information on HLB, see https://edis.ifas.ufl.edu/ cg086.

\section{Lethal Bronzing of Palms}

Lethal bronzing disease (LBD) is a fatal disease of palms first described in Texas in 1980 (McCoy et al. 1980) and discovered in Florida in 2006. It was first known as Texas Phoenix palm decline, because it was found to infect several palm species in the genus Phoenix. Since first described, the disease has been found to occur on multiple genera and is now most commonly called lethal bronzing. Among the palm species affected by LBD are the coconut palm, the queen palm, and the palmetto palm (Sabal palmetto), the official Florida state tree. The disease is caused by a phytoplasma, which is a type of bacterium that lacks a cell wall. Similar to HLB, the phytoplasma is limited to the phloem of palms and is vectored by an insect, most likely the palm cixiid, Haplaxius crudus. Disease symptoms are variable but include the reddish-bronze discoloration of leaves, premature fruit drop, and necrosis of inflorescences (Figure 5).

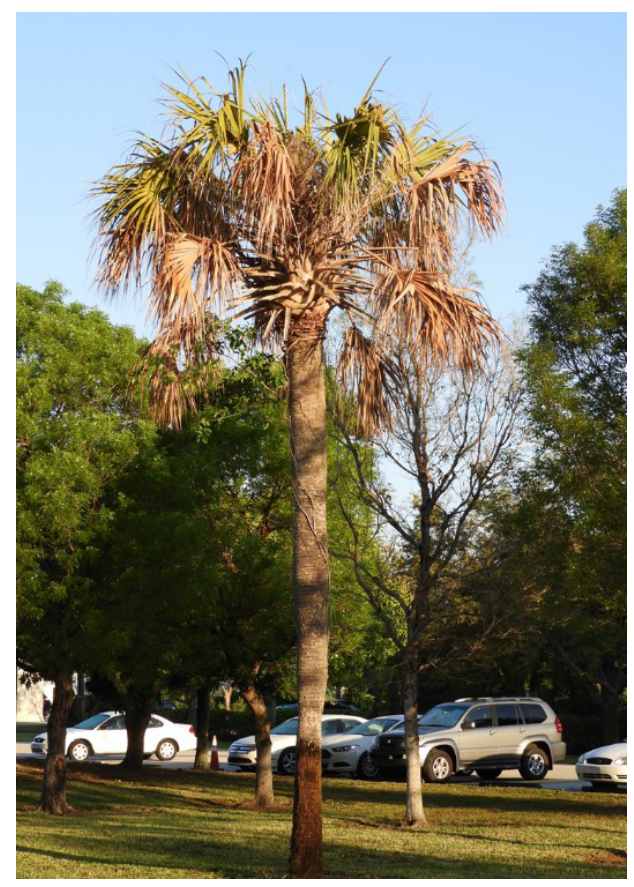

Figure 5. Lethal bronzing affected palm in a Florida residential area. Credits: Brian Bahder, UF/IFAS

Once a palm becomes infected, there is little that can be done. In urban areas where palm trees are of high ornamental value, oxytetracycline injections into the trunk have been used as a preventive measure. At the currently allowed rate, oxytetracycline does not cure palms once infection has occurred (Bahder and Helmick 2019). Because antibiotics are used as a preventive measure, it is generally recommended that they be applied at least quarterly during the year. For more information on LBD, see https://edis.ifas.ufl. edu/pp163.

\section{Annual Crops}

In addition to tree crops, streptomycin and oxytetracycline are registered for use in several annual crops. For example, streptomycin has been used in beans, celery, pepper, tomato, and potato to treat bacterial blights and bacterial spots. Bacterial spot is caused by the bacterium Xanthomonas perforans and other Xanthomonas species (Figure 6). It is a disease of tomato and pepper that has been treated with streptomycin with limited success. In general, streptomycin applications are more successful at controlling bacterial spot in the transplant house than in the field stage, where populations increase rapidly. To keep the disease under control, growers are using an integrated management program that includes use of resistant cultivars, sanitation, different cultural practices, and applications of copper, mancozeb, SAR inducers, and biologicals (Vidaver 2002). In addition to the limited efficacy of antibiotics, their use for disease protection of annual crops is economically not feasible for most growers, and there are concerns about the potential for selection of resistant pathogen strains.

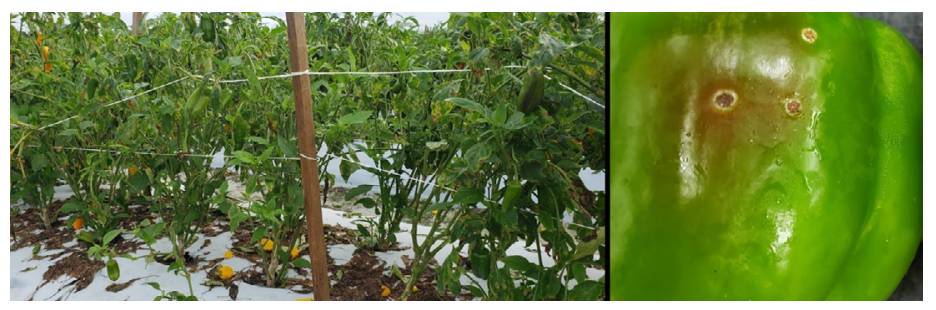

Figure 6. Bacterial spot on pepper plants and fruit. Credits: Pamela Roberts, UF/IFAS

\section{The Future of Antibiotic Use in Plants}

There are few antibiotics labeled for use on plants in the United States. Therefore, antibiotics are often classified together with fungicides in the FRAC code list, which is used by growers to consciously minimize risk of cross-resistance. In 2015, the antibiotic kasugamycin was registered for use in the United States, although it was labelled for select use in other countries prior to that (McManus 2014). The amount of kasugamycin used on crops in 2017 in the United States was negligible according to the most recent reports (USDA-NASS 2017). As of 2018, it was registered for use in cherries to control bacterial blast and canker, in walnuts to control walnut blight, and in pome fruits to control fire blight. Trials to determine the effectiveness of kasugamycin against other bacterial diseases, such as HLB 
or LBD, are in progress (McManus 2014). There is optimism for increasing the application of this product to crops because the absence of use in humans eliminates concerns about the potential of resistance development.

In addition to testing new antibiotic compounds, different application methods continue to be explored. Trunk injection of various chemical compounds has been used successfully to protect from numerous fungal, insect, and bacterial pests in crops such as avocado, grapevine, apple, and palms. This method helps minimize risk of drift and harm to nontarget organisms (Duker and Kubiak 2011). Although possible in most tree systems, the trunk-injection technique is most widely used in ornamental and forest trees. Commercial crop production systems can likely not rely on trunk injection due to the cost and labor requirements associated with the current methodologies. More efficient techniques for injecting antibiotics in orchard systems are being tested for safety and efficacy.

An in-depth review of the "top 10" most important plant bacterial diseases according to a global panel of plant pathologists (Mansfield et al. 2012) places several of the diseases discussed here on a list of the most economically and scientifically relevant. Although control of some of these diseases has been partially effective with the use of antibiotic applications, there are a range of devastating plant bacterial diseases that do not respond to known and available bactericides. Resistant cultivars and cultural control methods for many of these diseases continue to be developed, which can minimize the need for reliance on chemical control. For newly emerging diseases, the use of bactericide applications may provide a short-term period of control as resistant cultivars are discovered and made available to growers.

\section{References}

Bahder, B. W., and E. E. Helmick. 2019. Lethal Bronzing Disease (LBD). PP243. Gainesville: University of Florida Institute of Food and Agricultural Sciences. https://edis.ifas. ufl.edu/pp163

Da Graça, J. V. 1991. “Citrus Greening Disease.” Annu. Rev. Phytopathol. 29: 109-136.

Duker, A., and R. Kubiak. 2011. "Stem Injection of Prohexadione Carboxylic Acid to Protect Blossoms of Apple Trees from Fire Blight Infection." J. Plant Dis. Prot. 118 (5): $156-160$.
Graham, J. H., M. M. Dewdney, and M. E. Myers. 2010. "Streptomycin and Copper Formulations for Control of Citrus Canker on Grapefruit." Proc. Fla. State. Hort. Sci. 123: 92-99.

Hu, J., and N. Wang. 2016. "Evaluation of the Spatiotemporal Dynamics of Oxytetracycline and Its Control of Citrus Huanglongbing via Trunk Injection." Phytopath. 106 (12): 1495-1503.

Loper, J. E., M. D. Henkels, R. G. Roberts, M. J. Willet, and T. J. Smith. 1991. "Evaluation of Streptomycin, Oxytetracycline, and Copper Resistance of Erwinia amylovora Isolated from Pear Orchards in Washington State." Plant Dis. 75: 287-290.

Mansfield, J., S. Genin, et al. 2012. “Top 10 Plant Pathogenic Bacteria in Molecular Plant Pathology." Mol. Plant Path. 13 (6): 614-629.

McCoy, R. E., M. E. Miller, D. L. Thomas, and J. Amador. 1980. "Lethal Decline of Phoenix Palms in Texas Associated with Mycoplasmalike Organisms." Plant Dis. 64: 1038-1040.

McManus, P. S. 2014. "Does a Drop in the Bucket Make a Splash? Assessing the Impact of Antibiotic Use on Plants." Curr. Opin. Microbiol. 19: 76-82.

Stockwell, V. O., and B. Duffy. 2012. "Use of Antibiotics in Plant Agriculture." Rev. Sci. Tech. 31 (1): 199-210.

Vidaver, A. K. 2002. "Use of Antimicrobials in Plant Agriculture." Clinical Infectious Dis. 34 (3): S107-S110. 